\title{
Trends in female sexual behaviour and sexually transmitted diseases in London, 1982-1992
}

\author{
B A Evans, S M McCormack, P D Kell, J V Parry, R A Bond, K D MacRae
}

\begin{abstract}
Objective-To measure changes in female sexual behaviour, including condom use, and their relationship with the incidence of sexually transmitted and other genital diseases in women during the decade 1982-92.

Design-A prospective series of crosssectional surveys of sexual behaviour reported by a standardised self-administered questionnaire in new patients who presented for screening and diagnosis. Setting-A genitourinary medicine clinic in West London.

Subjects-4089 consecutive newly attending patients who completed sexual behaviour questionnaires during 1982, 1987, 1989 and 1992.

Main outcome measures-Trends in socio-demographic status, sexual behaviour, condom-use, sexually transmitted diseases and other genital infections diagnosed by routine clinical and laboratory methods.
\end{abstract}

Results-Women reported significantly increasing condom use (from $3 \cdot 6 \%$ to $20.7 \%$ ) and decreasing oral contraception (from $51 \cdot 2 \%$ to $40 \cdot 1 \%$ ), but the proportion who used no contraception $(23.6 \%$ to $\mathbf{2 4 . 7 \% )}$ and the proportion who had never been pregnant $(58 \cdot 3 \%$ to $59.9 \%)$ remained similar. Numbers of sexual partners in the preceding year decreased $(p<0.001)$ and an increasing proportion of women practised oral intercourse $(p<0.001)$. During the same period, there was a progressive decline $(p<0.001)$ in the incidence of gonorrhoea, chlamydial infection and trichomoniasis by approximately two-thirds. However, the incidence of vaginal candidosis $(p<0.001)$, bacterial vaginosis $(p<0.001)$ and genital warts $(p<0.01)$ increased.

Conclusions-Increasing use of condoms for vaginal intercourse with both regular and non-regular partners has been associated with a decrease in the incidence of gonorrhoea, chlamydial infection and trichomoniasis. There was also an increase in the practice of fellatio and a change in the spectrum of STD and other genital infections with little net reduction in morbidity. HIV infection showed no evidence of heterosexual spread.

(Genitourin Med 1995;71:286-280)

Keywords: STD; female; sexual behaviour

\section{Introduction}

The advent of AIDS has generated great interest in sexual behaviour and in the modifcations necessary to reduce the incidence of Human Immunodeficiency Virus (HIV) infection and other sexually transmitted diseases (STDs). Most studies have been limited to single periods of time and concentrated on numbers of sexual partners, sexual practices and condom usage. National surveys of sexual behaviour have provided no data on STD incidence in the samples studied. ${ }^{1-5}$ Wasserheit has reviewed changes in patterns of STD, but not linked them to sexual behaviour. ${ }^{6}$ Trend studies have been limited to college students assessed at irregular intervals with no account of changes in STD. ${ }^{78}$ Joffe et al also studied college women and elicited risk factors for self-reported STD over 3.5 years at college and found five or more sexual partners to be the only significant risk. ${ }^{9}$ Risk profiles for STD have been reported by Hart, ${ }^{10}$ but his sexual behaviour data are limited to numbers of partners over the past 3 months. Non-ulcerative STDs (gonorrhoea, chlamydial infection and trichomoniasis) have been shown to be independent risk factors for HIV infection among female prostitutes in Zaire. ${ }^{11}$

In this study, cohorts of women presenting for examination in 1982, 1987 and 1992 received questionnaires on sexual behaviour and underwent clinical examination with microscopy and laboratory tests for STDs and other genital infections. More detailed questions on condom use were added in 1987 at the start of the Government's Sexual Health Education Campaign.

\section{Methods}

This study is based on a self-administered standardised questionnaire on sexual behaviour given to consecutive new women patients attending a department of genitourinary medicine in West London. The initial questionnaire first used in 1982 contained questions on menarche, coitarche, partners in the last year, life-time partners and anal and oral intercourse stratified by penetration and ejaculation. ${ }^{12}{ }^{13}$ Two separate questions on condom-use were added in 1987: the first question applied to condom-use with regular partners and the second, to be answered only if applicable, with non-regular partners. Women who responded to the second question therefore self-assessed themselves as having nonregular partners. ${ }^{14}$ Questions on frequency of intercourse and cigarette smoking were added 
in 1992. The study included HIV testing from 1987 and a standardised self-assessment risk form from 1988 which included the offer of HIV testing. ${ }^{15}$

Socio-demographic, clinical and laboratory data were collected from the clinical records and all patients included in the study were screened for STDs and other genital infections as described previously. ${ }^{13}$ These included gonorrhoea, chlamydial infection, trichomoniasis, vaginal candidosis, genital herpes, genital warts, bacterial vaginosis and pelvic inflammatory disease. Cervical cytology was carried out routinely on all women unless recently tested. The study was planned to be repeated at intervals of 5 years from 1982. By 1987 it became apparent that more detailed questions were required on condom use and measurement of trend has been facilitated by incorporating a study undertaken in $1989 .{ }^{13}$

Analysis of data was carried out on the Charing Cross and Westminster Medical School's Sun $4 / 670$ computer system, utilising SPSS-X software. The chi square test for trend was used to assess the significance of changes observed over the decade 19821992.

Women who declined named HIV testing in 1992 had their serum stored and subsequently unlinked from other personal data and screened anonymously for HIV, hepatitis B, hepatitis C and HTLV-I and II. Aliquots of the specimens were combined in pools of 5 and tested for antibodies to human immunodeficiency virus (anti-HIV), hepatitis $C$ virus (anti-HCV), the core antigen of hepatitis B (anti-HBc) and human T-cell leukaemia/ lymphoma viruses types I and II (anti-HTLV I/II). Anti-HIV, anti-HCV and anti-HTLV I/II were screened for by commercial EIAs according to the manufacturers' given procedure (respectively: Wellcozyme HIV $1+2$ EIA, Murex Diagnostics Ltd, Dartford, UK; Ortho HCV 3.0 ELISA, Ortho Diagnostic Systems, High Wycombe, UK; HTLV-I/II ELISA, Cambridge Biotech Corp., Worcester, MA, USA). Specimens in pools that gave a reaction above or within $20 \%$ of the cut-off value were then tested individually by the screening assay. Confirmatory testing on reactive specimens was done by combinations of other screening assays (HIV, HTLV) and immunoblot (HTLV, HCV). Anti-Hbc testing of the pools was by a competitive assay (COMPRIA) employing an increased specimen volume ( $50 \mu \mathrm{l}$ versus $20 \mu \mathrm{l}$ in the standard assay) and a reduced cut-off. Any serum that inhibited binding of ${ }^{125} \mathrm{I}$ anti-Hbc by $>40 \%$ (standard assay $70 \%$ ) was considered reactive and was tested by an alternative RIA based on IgG class-specific antibody capture (GACRIA) to confirm the presence of anti$\mathrm{Hbc}$. The anti-Hbc reactive specimens were screened by commercial EIA for HBsAg, the presence of which was confirmed by neutralisation assay.

\section{Results}

A total of 3,042 women completed sexual behaviour questionnaires in 1982, 1987 and 1992. There were 67 women $(2 \cdot 2 \%)$ who refused. The age range of women in the study was 14-75 years, but 2,836 (93.9\%) were under 40 years of age. Trend tests show in table 1 that there was a significant decline in the proportion of teenage women from $18.8 \%$ in 1982 to $10.0 \%$ in 1992 ( $p<0.001$ ).

Ethnic origin was recorded in 3,035 of whom $2,529(83.3 \%)$ were white, 420 $(13.8 \%)$ were black and $57(1.9 \%)$ were Asian (table 1). The remaining 29 (1\%) were from other races. There was a significant increase in the proportion of black women $(p<0.05)$ and a more significant decrease in the proportion of white women $(p<0.001)$.

Marital status was recorded in 3,021 women, of whom $2,382(78.3 \%)$ were single, $376(12 \cdot 4 \%)$ were married, $244(8.0 \%)$ were separated or divorced and $13(0.4 \%)$ were widowed (table 1). There was a significant increase in the proportion of single women ( $p$ $<0.05$ ) and a significant decrease in the proportion of separated or divorced women $(\mathrm{p}<0.01)$.

Table 1 Age, racial origin, marital status, contraception and pregnancy

\begin{tabular}{|c|c|c|c|c|c|}
\hline & \multirow{2}{*}{$\begin{array}{l}1982 \\
(n=1025)\end{array}$} & \multirow{2}{*}{$\begin{array}{l}1987 \\
(n=1079)\end{array}$} & \multirow{2}{*}{$\begin{array}{l}1992 \\
(n=938)\end{array}$} & \multicolumn{2}{|c|}{ Chi-square for trend } \\
\hline & & & & $\chi^{2}$ & $p$ \\
\hline $\begin{array}{l}\text { Mean age (years) } \\
\text { Under } 20 \text { years }\end{array}$ & $\begin{array}{l}25 \cdot 6 \\
193(18 \cdot 8 \%)\end{array}$ & $\begin{array}{l}25 \cdot 8 \\
165(15 \cdot 3 \%)\end{array}$ & $\begin{array}{l}27 \cdot 1 \\
94(10 \cdot 0 \%)\end{array}$ & $32 \cdot 26$ & $<0.001$ \\
\hline $\begin{array}{r}\text { Racial origin: White } \\
\text { Black } \\
\text { Other }\end{array}$ & $\begin{array}{l}(\mathrm{n}=1024) \\
872(85 \cdot 2 \%) \\
131(12 \cdot 8 \%) \\
21(2 \cdot 0 \%)\end{array}$ & $\begin{array}{c}927(85 \cdot 9 \%) \\
136(12 \cdot 6 \%) \\
16(1 \cdot 5 \%)\end{array}$ & $\begin{array}{l}(n=932) \\
730(78 \cdot 3 \%) \\
153(16 \cdot 4 \%) \\
49(5 \cdot 3 \%)\end{array}$ & $\begin{array}{r}14.90 \\
4.97\end{array}$ & $\begin{array}{l}<0.001 \\
<0.05\end{array}$ \\
\hline $\begin{array}{l}\text { Single } \\
\text { Married } \\
\text { Separated/divorced }\end{array}$ & $\begin{array}{l}784(76 \cdot 5 \%) \\
134(13 \cdot 1 \%) \\
101(9 \cdot 9 \%)\end{array}$ & $\begin{array}{l}(\mathrm{n}=1076) \\
857(79 \cdot 6 \%) \\
120(11 \cdot 2 \%) \\
92(8 \cdot 6 \%)\end{array}$ & $\begin{array}{l}(n=920) \\
741(80 \cdot 5 \%) \\
122(13 \cdot 2 \%) \\
56(6 \cdot 1 \%)\end{array}$ & $\begin{array}{l}4 \cdot 86 \\
0 \cdot 005 \\
9 \cdot 55\end{array}$ & $\begin{array}{l}<0.05 \\
<0.95 \\
<0.01\end{array}$ \\
\hline $\begin{aligned} & \text { Contraception: } \text { None } \\
& \text { OC } \\
& \text { IUCD } \\
& \text { Condom } \\
& \text { Cap }\end{aligned}$ & $\begin{array}{c}253(24 \cdot 7 \%) \\
525(51 \cdot 2 \%) \\
107(10 \cdot 4 \%) \\
37(3 \cdot 6 \%) \\
58(5 \cdot 7 \%)\end{array}$ & $\begin{array}{c}(n=992) \\
243(24 \cdot 5 \%) \\
464(46 \cdot 8 \%) \\
68(6 \cdot 9 \%) \\
101(10 \cdot 2 \%) \\
69(7 \cdot 0 \%)\end{array}$ & $\begin{array}{c}(\mathrm{n}=931) \\
220(23.6 \%) \\
373(40 \cdot 1 \%) \\
41(4 \cdot 4 \%) \\
193(20 \cdot 7 \%) \\
42(4 \cdot 5 \%)\end{array}$ & $\begin{array}{r}0 \cdot 29 \\
24 \cdot 50 \\
29 \cdot 16 \\
190 \cdot 99 \\
1 \cdot 19\end{array}$ & $\begin{array}{l}<0.7 \\
<0.001 \\
<0.001 \\
<0.001 \\
0.3\end{array}$ \\
\hline Never pregnant & $607(59 \cdot 2 \%)$ & $\begin{array}{l}(\mathrm{n}=987) \\
591(59.9 \%)\end{array}$ & $\begin{array}{l}(n=903) \\
526(58 \cdot 3 \%)\end{array}$ & $0 \cdot 17$ & $<0.7$ \\
\hline
\end{tabular}


Table 2 Menarche, coitarche, partners and practices

\begin{tabular}{|c|c|c|c|c|c|}
\hline & \multirow{2}{*}{$\begin{array}{l}1982 \\
(n=1025)\end{array}$} & \multirow{2}{*}{$\begin{array}{l}1987 \\
(n=1079)\end{array}$} & \multirow{2}{*}{$\begin{array}{l}1992 \\
(n=938)\end{array}$} & \multicolumn{2}{|c|}{ Chi-square for trend } \\
\hline & & & & $\chi^{2}$ & $p$ \\
\hline $\begin{array}{l}\text { Menarche (years): } \\
\text { mean } \\
\text { median/mode }\end{array}$ & $\begin{array}{l}13 \cdot 1 \\
13\end{array}$ & $\begin{array}{l}13 \cdot 0 \\
13\end{array}$ & $\begin{array}{l}13 \cdot 1 \\
13\end{array}$ & - & \\
\hline $\begin{array}{l}\text { Coitarche (years): } \\
\text { mean } \\
\text { median/mode }\end{array}$ & $\begin{array}{l}17 \cdot 6 \\
17 / 16\end{array}$ & $\begin{array}{l}17 \cdot 4 \\
17 / 16\end{array}$ & $\begin{array}{l}17 \cdot 5 \\
17 / 17\end{array}$ & - & \\
\hline $\begin{array}{c}\text { Partners-in last year: } \\
>1 \\
>2 \\
>5\end{array}$ & $\begin{array}{c}583(56 \cdot 9 \%) \\
314(30 \cdot 6 \%) \\
57(5 \cdot 6 \%)\end{array}$ & $\begin{array}{c}583(54 \cdot 0 \%) \\
297(27 \cdot 5 \%) \\
55(5 \cdot 1 \%)\end{array}$ & $\begin{array}{c}463(49 \cdot 6 \%) \\
206(22 \cdot 0 \%) \\
28(3.0 \%)\end{array}$ & $\begin{array}{r}11 \cdot 09 \\
19 \cdot 10 \\
8 \cdot 18\end{array}$ & $\begin{array}{l}<0.001 \\
<0.001 \\
<0.01\end{array}$ \\
\hline $\begin{array}{c}- \text { in lifetime: } \\
>1 \\
>5 \\
>10 \\
>20\end{array}$ & $\begin{array}{c}929(90 \cdot 6 \%) \\
470(45 \cdot 9 \%) \\
231(22 \cdot 5 \%) \\
84(8 \cdot 2 \%)\end{array}$ & $\begin{array}{l}980(90 \cdot 8 \%) \\
549(50 \cdot 9 \%) \\
257(23 \cdot 8 \%) \\
103(9 \cdot 5 \%)\end{array}$ & $\begin{array}{c}859(91 \cdot 6 \%) \\
478(51 \cdot 0 \%) \\
216(23 \cdot 0 \%) \\
71(7 \cdot 6 \%)\end{array}$ & $\begin{array}{l}0 \cdot 53 \\
5 \cdot 29 \\
0 \cdot 078 \\
0 \cdot 22\end{array}$ & $\begin{array}{l}<0.5 \\
<0.02 \\
<0.8 \\
<0.7\end{array}$ \\
\hline $\begin{array}{l}\text { Anal intercourse: } \\
\text { penetration } \\
\text { ejaculation }\end{array}$ & $\begin{array}{c}200(19 \cdot 5 \%) \\
90(8 \cdot 8 \%)\end{array}$ & $\begin{array}{c}164(15 \cdot 2 \%) \\
80(8 \cdot 2 \%)\end{array}$ & $\begin{array}{l}193(20 \cdot 6 \%) \\
106(11 \cdot 3 \%)\end{array}$ & $\begin{array}{l}0 \cdot 25 \\
3 \cdot 24\end{array}$ & $\begin{array}{l}<0.9 \\
<0.2\end{array}$ \\
\hline $\begin{array}{l}\text { Oral intercourse: } \\
\text { penetration } \\
\text { ejaculation }\end{array}$ & $\begin{array}{l}714(69 \cdot 7 \%) \\
378(36 \cdot 9 \%)\end{array}$ & $\begin{array}{l}825(76 \cdot 4 \%) \\
453(42 \cdot 0 \%)\end{array}$ & $\begin{array}{l}768(81.9 \%) \\
482(51.4 \%)\end{array}$ & $\begin{array}{l}41 \cdot 34 \\
41 \cdot 99\end{array}$ & $\begin{array}{l}<0.001 \\
<0.001\end{array}$ \\
\hline
\end{tabular}

1 Contraception and pregnancy

A marked downtrend in the use of oral contraception and the intra-uterine contraceptive device is shown in table 1 , together with a marked uptrend in condom-use for contraception from $3.6 \%$ in 1982 to $20.7 \%$ in 1992 $(\mathrm{p}<0.001)$. Despite this move from more reliable forms of contraception to the condom, there was no significant change in the proportion of women who had been pregnant $(58.3 \%-59.9 \%)$, or in the proportion of women who did not use any form of contraception $(23 \cdot 6 \%-24 \cdot 7 \%)$. Figures for married women not using contraception were slightly higher $(33.6 \%$ in 1982 , falling to $27.6 \%$ in 1992), but the downtrend was not significant $(\mathrm{p}<0.5)$.

\section{Sexual behaviour}

The age of menarche remained unchanged, with a median and modal age of 13 years in all 3 years (table 2). For coitarche the median age was 17 years in 1982,1987 and 1992 and the modal age 16 years in 1982 and 1987, and 17 years in 1992 .

The numbers of sexual partners reported in the last year all fell significantly, with the biggest change in those reporting more than two partners which fell from $30.6 \%$ in 1982 to $22.0 \%$ in $1992(\mathrm{p}<0.001)$. There was only one significant change in the reported numbers of partners in the womens' lifetimes: the increased proportion with more than 5 partners $(p<0.02)$.

Whereas the practice of anal intercourse did not show significant trends during this decade, oral intercourse was practised by a significantly increased proportion of women and those who practised oral ejaculation rose from $36.9 \%$ in 1982 to $51.4 \%$ in 1992 $(\mathrm{p}<0.001)$.

\section{Condom usage}

The data from a similar study undertaken in 1989 were used to enable the calculation of trends in condom use with regular and nonregular partners between 1987 and 1992 . During this period, there were highly significant increases in the proportion of women using condoms with both regular and nonregular partners, apart from occasional use with non-regular partners (table 3). More than half of the study group never used condoms in 1987, but by 1992 this had fallen to two fifths who never used them with regular partners and to one fifth who never used them with non-regular partners. In $1992,43.5 \%$ of women recorded always using condoms with non-regular partners.

Table 3 Condom use

\begin{tabular}{|c|c|c|c|c|c|}
\hline & \multirow[b]{2}{*}{1987} & \multirow[b]{2}{*}{1989} & \multirow[b]{2}{*}{1992} & \multicolumn{2}{|c|}{ Chi-square for trend } \\
\hline & & & & $\chi^{2}$ & $p$ \\
\hline $\begin{array}{l}\text { Condom use } \\
\text { with regular partners: } \\
\text { never } \\
\text { occasionally } \\
\text { often } \\
\text { always }\end{array}$ & $\begin{array}{l}(\mathrm{n}=1066) \\
672(63 \cdot 0 \%) \\
262(24 \cdot 6 \%) \\
70(6 \cdot 6 \%) \\
62(5 \cdot 8 \%)\end{array}$ & $\begin{array}{l}(\mathrm{n}=1015) \\
490(48 \cdot 3 \%) \\
317(31 \cdot 2 \%) \\
111(10 \cdot 9 \%) \\
97(9 \cdot 6 \%)\end{array}$ & $\begin{array}{l}(n=936) \\
376(40 \cdot 2 \%) \\
305(32 \cdot 6 \%) \\
149(15 \cdot 9 \%) \\
106(11 \cdot 3 \%)\end{array}$ & $\begin{array}{r}109 \cdot 62 \\
16 \cdot 24 \\
48 \cdot 16 \\
20 \cdot 70\end{array}$ & $\begin{array}{l}<0.001 \\
<0.001 \\
<0.001 \\
<0.001\end{array}$ \\
\hline $\begin{array}{l}\text { with non-regular partners: } \\
\text { never } \\
\text { occasionally } \\
\text { often } \\
\text { always }\end{array}$ & $\begin{array}{l}(\mathrm{n}=424) \\
225(53 \cdot 1 \%) \\
99(23 \cdot 3 \%) \\
44(10 \cdot 4 \%) \\
56(13 \cdot 2 \%)\end{array}$ & $\begin{array}{l}(\mathrm{n}=368) \\
110(29 \cdot 9 \%) \\
83(22 \cdot 6 \%) \\
69(18 \cdot 7 \%) \\
106(28 \cdot 8 \%)\end{array}$ & $\begin{array}{r}(\mathrm{n}=416) \\
83(20 \cdot 0 \%) \\
75(18 \cdot 0 \%) \\
77(18 \cdot 5 \%) \\
181(43 \cdot 5 \%)\end{array}$ & $\begin{array}{r}112 \cdot 36 \\
3 \cdot 61 \\
11 \cdot 70 \\
111 \cdot 30\end{array}$ & $\begin{array}{l}<0.001 \\
<0.1 \\
<0.01 \\
<0.001\end{array}$ \\
\hline
\end{tabular}




\begin{tabular}{|c|c|c|c|c|c|}
\hline & \multirow{2}{*}{$\begin{array}{l}1982 \\
n=1025\end{array}$} & \multirow{2}{*}{$\begin{array}{l}1987 \\
n=1079\end{array}$} & \multirow{2}{*}{$\begin{array}{l}1992 \\
n=938\end{array}$} & \multicolumn{2}{|c|}{ Chi-square for trend } \\
\hline & & & & $\chi^{2}$ & $p$ \\
\hline $\begin{array}{l}\text { Gonorrhoea } \\
\text { Chlamydial infection } \\
\text { NGU contact } \\
\text { Trichomoniasis } \\
\text { Candidosis } \\
\text { Genital herpes } \\
\text { Genital warts } \\
\text { Bacterial vaginosis } \\
\text { Pelvic inflammatory disease } \\
\text { No abnormality detected }\end{array}$ & $\begin{aligned} & 91(8 \cdot 9 \%) \\
& 175(17 \cdot 1 \%) \\
& 248(24 \cdot 2 \%) \\
& 99(9 \cdot 7 \%) \\
& 236(23 \cdot 0 \%) \\
& 58(5 \cdot 7 \%) \\
& 65(6 \cdot 3 \%) \\
& 40(3 \cdot 9 \%) \\
& 22(2 \cdot 1 \%) \\
& 237(23 \cdot 1 \%)\end{aligned}$ & $\begin{array}{c}54(5 \cdot 0 \%) \\
84(7 \cdot 8 \%) \\
174(16 \cdot 1 \%) \\
59(5 \cdot 5 \%) \\
287(26 \cdot 6 \%) \\
66(6 \cdot 1 \%) \\
128(11 \cdot 9 \%) \\
49(4 \cdot 5 \%) \\
11(1 \cdot 0 \%) \\
269(24 \cdot 9 \%)\end{array}$ & $\begin{array}{c}23(2 \cdot 5 \%) \\
53(5 \cdot 7 \%) \\
120(12 \cdot 8 \%) \\
27(2 \cdot 9 \%) \\
310(33 \cdot 0 \%) \\
65(6 \cdot 9 \%) \\
93(9 \cdot 9 \%) \\
90(9 \cdot 6 \%) \\
18(1 \cdot 9 \%) \\
270(28 \cdot 8 \%)\end{array}$ & $\begin{array}{l}47 \cdot 93 \\
78 \cdot 0 \\
45 \cdot 3 \\
47 \cdot 5 \\
24 \cdot 5 \\
1 \cdot 32 \\
9 \cdot 12 \\
27 \cdot 67 \\
0 \cdot 16 \\
8 \cdot 12\end{array}$ & $\begin{array}{l}<0.001 \\
<0.001 \\
<0.001 \\
<0.001 \\
<0.001 \\
<0.3 \\
<0.01 \\
<0.001 \\
<0.7 \\
<0.01\end{array}$ \\
\hline
\end{tabular}

4 Sexually transmitted diseases and genital infections

The pattern of sexually transmitted diseases and other genital infections in these cohorts of women changed dramatically between 1982 and 1992 (table 4). The incidence of gonorrhoea, chlamydial infection and trichomoniasis all showed highly significant downtrends $(p<0.001)$. By contrast, vaginal candidosis and bacterial vaginosis both showed significant uptrends $(p<0.001)$. Genital warts showed a significant uptrend overall ( $p<0.01$ ), but the incidence in $1992(9.9 \%)$ was less than that in $1987(11.9 \%)$. Genital herpes and pelvic inflammatory disease both showed no significant change. Women in whom no abnormality was detected (NAD) increased in proportion from $23.1 \%$ in 1982 to $28.6 \%$ in $1992(p<0.01)$. Syphilis was diagnosed in three women $(0.3 \%)$ in 1982 , (one early syphilis and two late syphilis) and no woman in 1987 and 1992. These trends reflect the national figures. ${ }^{16}$

\section{Cervical cytology}

Changes due to human papillomavirus $(p<0.01)$ and mild dyskaryosis $(p<0.05)$ both proportionately increased but there was no change in high grade lesions (table 5 ).

$6 H I V$, hepatitis $B$, hepatitis $C$ and human $T$ cell leukaemiallymphoma (HTLV-I/II) virus infection

All women were screened for HIV infection in 1987 and three were positive $(0.3 \%)$. In 1992 , 367 were tested after informed consent $(39.7 \%)$ and 558 were tested anonymously; none was positive. Twenty seven out of 647 women $(4 \cdot 2 \%)$ were hepatitis B core antibody (anti-Hbc) positive in 1987 and 12 out of 558 $(2 \cdot 2 \%)$ were positive in 1992 . Hepatitis C testing and HTLV-I/II testing were carried out in 1992 only; one woman out of 558 $(0.2 \%)$ was anti-HCV positive and two out of $558(0 \cdot 4 \%)$ were anti-HTLVI/II positive.

\section{Discussion}

Over the past decade, there has been an unprecedented campaign to modify sexual behaviour under the threat of a worldwide epidemic of HIV infection. This campaign has been focused on promotion of condom use for sexual intercourse, but its effectiveness is assumed rather than proven and any benefits have remained largely unquantified. ${ }^{17}$

Our findings show significant changes in age and racial origin of women attending our clinic over this decade: there was a decrease in the proportion of teenagers and white women and an increase in the proportion of black women. We suggest that this has resulted from changes in sexual behaviour which have decreased the risk of acquiring STD by teenagers and white women generally, but that this has not occurred among black women. Although the advent of HIV infection and the promotion of testing have also brought women to the clinic who might otherwise not have attended, those who came solely for HIV testing and declined screening for STD were automatically excluded from the study.

Concurrent observations of sexual behaviour and STD incidence between 1982 and 1992 have shown a clear association between increasing condom use and decreasing incidence of three STDs: gonorrhoea, chlamydial infection and trichomoniasis. In a previous study of risk profiles in 1982, we showed that these infections were independent risks with predictive value for each other. ${ }^{13}$ This study pre-dated the universal promotion of condoms for prevention of STDs and the subsequent decline in prevalence has occurred in association with increasing condom usage. Use of the cap or diaphragm by a small proportion of women remained similar over the same period.

Nevertheless, during the same decade we observed a highly significant increase in the incidence of both vaginal candidosis and bac-

\begin{tabular}{|c|c|c|c|c|c|}
\hline & \multirow{2}{*}{$\begin{array}{l}1982 \\
(n=813)\end{array}$} & \multirow{2}{*}{$\begin{array}{l}1987 \\
(n=527)\end{array}$} & \multirow{2}{*}{$\begin{array}{l}1992 \\
(n=835)\end{array}$} & \multicolumn{2}{|c|}{ Chi-square for trend } \\
\hline & & & & $\chi^{2}$ & $p$ \\
\hline $\begin{array}{l}\text { Human papilloma virus } \\
\text { Dyskaryosis: }\end{array}$ & $21(2 \cdot 6 \%)$ & $38(7 \cdot 2 \%)$ & $43(5 \cdot 1 \%)$ & $7 \cdot 62$ & $<0.01$ \\
\hline $\begin{array}{l}\text { Mild } \\
\text { Moderate } \\
\text { Severe }\end{array}$ & $\begin{array}{r}25(3 \cdot 1 \%) \\
5(0.5 \%) \\
1(0.1 \%)\end{array}$ & $\begin{array}{r}26(4 \cdot 9 \%) \\
7(1 \cdot 3 \%) \\
3(0 \cdot 6 \%)\end{array}$ & $\begin{array}{r}42(5 \cdot 0 \%) \\
3(0 \cdot 4 \%) \\
2(0 \cdot 2 \%)\end{array}$ & $\begin{array}{l}4 \cdot 16 \\
1 \cdot 44 \\
0 \cdot 26\end{array}$ & $\begin{array}{l}<0.05 \\
<0.3 \\
<0.7\end{array}$ \\
\hline
\end{tabular}


terial vaginosis, despite dramatic improvements in the treatment of both these conditions. One obvious explanation for this discrepancy is that neither of these conditions is sexually transmitted. However, this explanation does not account for the uptrend, especially as the reported numbers of recent sexual partners significantly declined. Apart from condom usage, the only other form of sexual behaviour which we found to have increased in prevalence was fellatio. Multivariate analysis using logistic regression models is being used to examine for possible independent relationships between these variables.

In contrast to the bacterial STDs, the two most prevalent viral STDs, genital warts and genital herpes, have not been controlled by condom usage. Latent infection with both herpes simplex virus and human papilloma virus is much more prevalent than clinical disease and both viruses infect stratified squamous epithelium of the external genitalia and may therefore be transmitted independently of peno-vaginal penetration, thus circumventing the condom barrier. Moreover, both conditions are recurrent and subject to transmission by asymptomatic virus shedding.

Despite the considerable resources directed to prevention of unwanted pregnancies as well as to STD, we found that about a quarter of women in each sample reported using no contraception at all across the decade of our study. Only $12 \%$ of women in the study were married, so a substantial proportion were exposed to pregnancy outside marriage. Could a more persuasive campaign prove more effective or have the limits of health education been reached?

While the predicted epidemic heterosexual spread of HIV infection in the United Kingdom has yet to develop, ${ }^{18}$ the health education measures generated by this threat appear to have yielded benefits in the control of bacterial STDs. However, the net benefit in morbidity has been limited in that one dominant group of infections, the bacterial STDs, has been replaced by others, the viral STDs (including cervical HPV infection) and vaginal infections due to more ubiquitous organisms. HIV infection, like hepatitis B infection and syphilis, has shown no evidence of heterosexual spread.

1 Johnson AM, Wordsworth J, Wellings $\mathrm{K}$, Bradshaw S, Field J. Sexual lifestyles and HIV risk. Nature 1992;360:410-2.

2 Anderson JE, Dahlberg LL. High risk sexual behaviour in the general population. Results from a national survey, 1988-1990. Sex Transm Dis 1992;19:320-5.

3 Herlitz C. Sexual behaviour in the general population of Sweden. Soc Sci Med 1993;36:1535-40.

4 Seidman SN, Reider RO. A review of sexual behaviour in the United States. AMF Psychiatry 1994;151:330-41.

5 Aral SO. Sexual behaviour in sexually transmitted disease research. An overview. Sex Transm Dis 1994;21suppl: 559-64.

6 Wasserheit JN. Effect of changes in human ecology and behaviour on patterns of sexually transmitted diseases, including human immunodeficiency virus infection. Proc Natl Acad Sci USA 1994;91:2430-5.

7 De Buono BA, Zinner SH, Daamen M, McCormack WM. Sexual behaviour of college women in 1975, 1986 and 1989. N Engl F Med 1990;12:821-5.

8 Hale RW, Char DF, Nagy K, Stocker N. Seventeen year review of sexual and contraceptive behaviour on a college campus. Am f Obstet Gynecol 1993;168:1833-7.

9 Joffe GP, Foxman B, Schmidt AJ, et al. Multiple partners and partner choice as risk factors for sexually transmitted diseases among female college students. Sex Transm Dis 1992;19:272-8.

10 Hart G. Risk profiles and epidemiologic interrelationships of sexually transmitted diseases. Sex Transm Dis 1993; 20:126-36.

11 Laga M, Manoka A, Kivuvu M, et al. Non-ulcerative sexually transmitted diseases as risk factors for HIV-1 transmission in women: results from a cohort study. AIDS 1993;7:95-102.

12 Evans BA, Bond RA, MacRae KD. Sexual behaviour of women attending a genitourinary medicine clinic. Genitourin Med 1988;64:43-8.

13 Evans BA, Tasker T, MacRae KD. Risk profiles for genital infection in women. Genitourin Med 1993;69:257-61.

14 Evans BA, McCormack SM, Bond RA, MacRae KD, Thorp RW. Human immunodeficiency virus infection, hepatitis $B$ virus infection and sexual behaviour of women attending a genitourinary medicine clinic. $B M \mathcal{F}$ women attending

15 Evans BA, McCormack SM, Bond RA, MacRae KD. Trends in sexual behaviour and HIV testing among women at a genitourinary medicine clinic during the advent of AIDS. Genitourin Med 1991;67:194-8.

16 DH Statistics Division (SD2B). New cases seen at NHS genitourinary medicine clinics in England. 1993 annual figures. Summary Information from KC60, 1994

$17 \mathrm{De}$ Vincenzi I for the European Study Group on Heterosexual Transmission of HIV. A longitudinal study of human immunodeficiency virus transmission by heterosexual partners. $N$ Engl $f$ Med 1994;331:341-6.

18 Anderson RM, May RM. Epidemiological parameters of HIV transmission. Nature 1988;333:514-9. 